\title{
A Survey on Morality Cultivation in College English Instruction for Non-English-Majored Undergraduate Freshmen
}

\author{
Yougen Lou \\ School of Foreign Studies, Yangtze University, Jingzhou, China \\ Email: louyougen@163.com
}

How to cite this paper: Lou, Y.G. (2022) A Survey on Morality Cultivation in College English Instruction for Non-English-Majored Undergraduate Freshmen. Open Access Library Journal, 9: e8175.

https://doi.org/10.4236/oalib.1108175

Received: November 10, 2021

Accepted: January 1, 2022

Published: January 4, 2022

Copyright $\odot 2022$ by author(s) and Open Access Library Inc.

This work is licensed under the Creative Commons Attribution International License (CC BY 4.0).

http://creativecommons.org/licenses/by/4.0/

\begin{abstract}
The morality cultivation in course instruction is a kind of new teaching idea. One hundred and seventy four non-English-majored undergraduate freshmen from Yangtze University filled out the questionnaire online on the morality cultivation in College English course instruction. Data collected from 174 questionnaires on morality cultivation in College English course instruction were analyzed in this paper. The results in this study showed that: 1) Sixty-eight participants (39.08\%) thought that the content proportion of morality cultivation in College English textbooks was low; 66 participants (37.93\%) and 55 participants (31.61\%) thought that the appropriate content proportion of morality cultivation in College English textbooks, respectively, was " $21 \%$ $30 \%$ " and " $11 \%-20 \% " ; 2)$ More than 80 participants believed that morality cultivation in college English course instruction had increased their interest in English learning and had a positive effect on their English learning; 3) 148 participants (85.06\%) hoped to learn "knowledge related to correct ideals, beliefs and values" and only 1 participant (0.57\%) strongly disagreed to learn "knowledge related to correct ideals, beliefs and values", 141 participants (81.03\%) hoped to learn "knowledge related to Chinese culture", 121 participants (69.54\%) hoped to learn "knowledge related to Chinese social system" and 122 participants (69.94\%) hoped to learn "knowledge related to career planning" in College English course instruction.
\end{abstract}

\section{Subject Areas}

Higher Education, Language Education

\section{Keywords}

College Freshmen, College English, The Morality Cultivation, Foreign Language Course Instruction 


\section{Introduction}

Recent years, more people and organizations focus on the morality cultivation applied in the courses such as College English, maths in colleges and universities. President Xi Jinping emphasized "all other courses should keep a good section of the channel and plant a good field of responsibility, so that all kinds of courses can go with ideological and political theory courses in the same direction to form a synergistic effect" at the National Conference on the morality cultivation in Colleges and Universities from 7 to 8 December, 2016 [1]. In September 2018 , Curricula related to the morality cultivation and major as the morality cultivation were strengthened in the "Opinions from the Ministry of Education of the People's Republic of China on Accelerating the Construction of High-level Undergraduate Education to Comprehensively Improve the Ability to Cultivate Talents" [2]. In June 2020, the construction of Curricula related to the morality cultivation in colleges or universities to be comprehensively promoted was required by the "Guidelines for the Construction of Curricula related to the Morality Cultivation in Colleges and Universities" issued by the Ministry of Education [3]. Researchers [4]-[9] spent time and energy to study the morality cultivation applied in curricula in colleges or universities. Their studies were related to theoretical exploration on the morality cultivation applied in College English. There are few empirical studies on the morality cultivation applied in College English. The present paper is related to an empirical study on the morality cultivation applied in College English. This paper will study the morality cultivation applied in College English from empirical perspective to explore the freshmen's views and needs on the morality cultivation applied in College English.

This paper tries to answer the following questions:

1) What are the views of freshmen on the content proportion of the morality cultivation in college English textbooks?

2) What is the positive impact of the morality cultivation on freshmen for their College English learning?

3) What kind of knowledge do college freshmen most hope to learn from the morality cultivation in College English?

\section{Methods}

\subsection{Participant}

The link to the questionnaire was sent to 4 College English teachers (the author's colleagues), then they sent the link to the questionnaire to their first-year nonEnglish-majored undergraduates. According to the data from the questionnaire, participants in this study are 174 (68 males and 106 females) first-year nonEnglish-majored undergraduates from Yangtze University in Hubei province majored as humanities and history (71), science and engineering (41), economics and management (31) and other majors (31)) to fill in the Questionnaire on the morality cultivation applied in College English. Their average age is 18 years old. 


\subsection{Tool}

The tool used in this study to explore the fresh men's views and needs on the morality cultivation applied in College English is questionnaire with the Likert scale (1) strongly disagree; 2) disagree; 3) not sure; 4) agree; 5) strongly agree). The contents (the rate of the morality cultivation in the College English textbooks, effects of the morality cultivation on students' College English learning, the Chinese culture, the Chinese social system, the career planning, and correct ideals, beliefs, values) are designed in the questionnaire to obtain participants' views and needs. The questionnaire includes two parts with 20 questions. The first part of the questionnaire is on the personal information of the participants (age, gender and major, 3 questions), and the second part of the questionnaire is about the fresh men's views on the morality cultivation in College English and their learning needs 17 questions). The questionnaire was revised by 5 different College English teachers (the author's colleagues) several times before being used, then 10 students were invited to try it out. The questionnaire is valid. And the questionnaire ( $\alpha=0.813)$ is good. On June 11-24, 2020, 174 Yangtze University freshmen filled out the questionnaire online.

\subsection{Data Collection and Processing}

All the 174 questionnaires filled out by 174 freshmen from Yangtze University online were valid. All the 174 questionnaire data were analyzed and processed by Questionnaire star (https://www.wjx.cn/) to obtain the results.

\section{Results}

\subsection{Results of Responses on Content Proportion of the Morality Cultivation in College English Textbooks}

From Table 1, we can know that for the question "Current content proportion of the morality cultivation in College English textbooks is low", 68 (56 and 12) participants chose "agree and strongly agree", only 6 participants chose "strongly disagree" and 68 participants chose "not sure"; for the question "What is the appropriate content proportion of morality cultivation in College English textbooks", 66 participants chose " $21 \%$ - 30\%", 55 participants chose " $11 \%-20 \%$ ", 23 participants chose " $31 \%-40 \%$ " and 22 participants chose " $10 \%$ below", only 8participants chose " $41 \%-50 \%$ ".

\subsection{Effects of the Morality Cultivation on Freshmen in Their College English Learning}

From Table 2, we can see effects of the morality cultivation on freshmen's College English learning. Eighty participants (45.98\%) agreed or strongly agreed "the morality cultivation in College English has promoted my English learning effect", only 6 participants strongly disagreed "the morality cultivation in College English has promoted my English learning effect". One hundred and eight participants (61.80\%) agreed or strongly agreed with "my interest in English learning has been promoted through education on inspiration, outlook on life, 
Table 1. Results of responses on content proportion of the morality cultivation in College English textbooks.

\begin{tabular}{cccc}
\hline $\begin{array}{c}\text { Current content proportion of MC } \\
\text { in College English textbooks: low }\end{array}$ & Number & Number & $\begin{array}{c}\text { Appropriate content proportion of MC } \\
\text { in College English textbooks }\end{array}$ \\
\hline Choice & 6 & 22 & percentage \\
\hline Strongly disagree & 32 & 55 & $10 \%$ below \\
Disagree & 68 & 66 & $11 \%-20 \%$ \\
Not sure & 56 & 23 & $31 \%-40 \%$ \\
Agree & 12 & 8 & $41 \%-50 \%$ \\
\hline
\end{tabular}

$\mathrm{MC}=$ the Morality Cultivation;

Table 2. Effects of the morality cultivation on freshmen in their College English Learning.

\begin{tabular}{|c|c|c|c|c|c|c|c|c|}
\hline \multirow[t]{2}{*}{$\begin{array}{c}\text { Choice } \\
\text { Choice } \\
\text { Q }\end{array}$} & \multicolumn{2}{|c|}{$\begin{array}{l}\text { Promotion of } \\
\text { English } \\
\text { learning effect }\end{array}$} & \multicolumn{2}{|c|}{$\begin{array}{l}\text { Promotion of interest } \\
\text { in English learning through } \\
\text { education on inspiration, } \\
\text { outlook on life, and values }\end{array}$} & \multicolumn{2}{|c|}{$\begin{array}{l}\text { learning online MC } \\
\text { resource before class } \\
\text { has Increased my interest } \\
\text { in English learning }\end{array}$} & \multicolumn{2}{|c|}{$\begin{array}{l}\text { the English content I learned in class } \\
\text { was consolidated and internalized by } \\
\text { after-school tasks such as reflection, } \\
\text { textbook video reproduction, social } \\
\text { practice, etc. }\end{array}$} \\
\hline & $\mathrm{N}$ & $\mathrm{P}(\%)$ & $\mathrm{N}$ & $\mathrm{P}(\%)$ & $\mathrm{N}$ & $\mathrm{P}(\%)$ & $\mathrm{N}$ & $\mathrm{P}(\%)$ \\
\hline Strongly disagree & 6 & 3.45 & 4 & 2.3 & 4 & 2.3 & 1 & 0.57 \\
\hline Disagree & 21 & 12.07 & 13 & 7.47 & 12 & 6.9 & 8 & 4.6 \\
\hline Not sure & 67 & 38.51 & 49 & 28.16 & 41 & 23.56 & 47 & 27.01 \\
\hline Agree & 67 & 38.51 & 91 & 52.3 & 101 & 58.04 & 101 & 58.05 \\
\hline $\begin{array}{c}\text { Strongly } \\
\text { agree }\end{array}$ & 13 & 7.47 & 17 & 9.77 & 16 & 9.2 & 17 & 9.77 \\
\hline
\end{tabular}

Q stands for Question; $\mathrm{N}$ for number; P for percentage.

and values", only 4 participants (2.3\%) strongly disagreed with "my interest in English learning has been promoted through education on inspiration, outlook on life, and values". One hundred and seventeen participants (67.06\%) agreed or strongly agreed with "learning online MC resource before class has Increased my interest in English learning" and only 4 participants (2.3\%) strongly disagreed with "learning online MC resource before class has Increased my interest in English learning". One hundred and eighteen participants (67.82\%) agreed or strongly agreed with "the English content I learned in class was consolidated and internalized by after-school tasks such as reflection, textbook video reproduction, social practice, etc." and only 1 participant (0.57\%) strongly disagreed with "the English content I learned in class was consolidated and internalized by after-school tasks such as reflection, textbook video reproduction, social practice, etc.".

\subsection{Content for College Freshmen Hope to Learn from the Morality Cultivation in College English}

From Table 3, we may see that 141 participants (81.03\%) agreed or strongly agreed to learn "knowledge related to Chinese culture" and only 5 participants 
Table 3. Content for college freshmen hope to learn from the morality cultivation in College English.

\begin{tabular}{|c|c|c|c|c|c|c|c|c|}
\hline \multirow{2}{*}{$\begin{array}{c}\text { Choice } \\
\text { Choice } \\
\text { Q }\end{array}$} & \multicolumn{2}{|c|}{$\begin{array}{c}\text { Knowledge related to } \\
\text { Chinese culture }\end{array}$} & \multicolumn{2}{|c|}{$\begin{array}{l}\text { Knowledge related to } \\
\text { Chinese social system }\end{array}$} & \multicolumn{2}{|c|}{$\begin{array}{c}\text { Knowledge related to } \\
\text { career planning }\end{array}$} & \multicolumn{2}{|c|}{$\begin{array}{l}\text { Knowledge related to correct } \\
\text { ideals, beliefs and values }\end{array}$} \\
\hline & $\mathrm{N}$ & $\mathrm{P}(\%)$ & $\mathrm{N}$ & $\mathrm{P}(\%)$ & $\mathrm{N}$ & $\mathrm{P}(\%)$ & $\mathrm{N}$ & $\mathrm{P}(\%)$ \\
\hline Strongly disagree & 0 & 0 & 2 & 1.15 & 1 & 0.57 & 1 & 0.57 \\
\hline Disagree & 5 & 2.87 & 11 & 6.32 & 9 & 5.17 & 3 & 1.72 \\
\hline Not sure & 28 & 16.09 & 40 & 22.99 & 42 & 24.14 & 22 & 12.64 \\
\hline Agree & 104 & 59.77 & 97 & 55.75 & 103 & 59.2 & 115 & 66.09 \\
\hline $\begin{array}{c}\text { Strongly } \\
\text { agree }\end{array}$ & 37 & 21.26 & 24 & 13.79 & 19 & 10.92 & 33 & 18.97 \\
\hline
\end{tabular}

Q stands for Question; N for number; P for percentage.

disagreed to learn "knowledge related to Chinese culture"; 121 participants (69.54\%) agreed or strongly agreed to learn "knowledge related to Chinese social system" and only 2 participants strongly disagreed to learn "knowledge related to Chinese social system"; 122 participants (69.94\%) hoped to learn "knowledge related to career planning" and only 1 participant $(0.57 \%)$ strongly disagreed to learn "knowledge related to career planning"; 148 participants (85.06\%) hoped to learn "knowledge related to correct ideals, beliefs and values" and only 1 participant (0.57\%) strongly disagreed to learn "knowledge related to correct ideals, beliefs and values".

\section{Discussion}

College English is a compulsory course with the widest audience and the longest learning time for college students in China. It is not only a new teaching idea but also a new teaching content to integrate the ideological and political elements of moral cultivation into college English teaching. The morality cultivation applied in College English course will not only meet the needs of freshmen to learn English knowledge, but also meet their needs to improve their ideological and political literacy.

Teaching materials are, the main carrier of teaching content, the basic guarantee for achieving the teaching goals [10] and also the important media for college students to receive positive guidance in terms of ideals, beliefs, values, and ethics. At present, the content of College English textbooks is mostly selected from articles on Western culture, political system, social development, etc., while articles from China's excellent culture, political system, and social development achievements are few or not, leading to the situation that the content ratio of the morality cultivation in the current college English textbooks is low. However, the emergence of this situation (the content ratio of the morality cultivation in the current college English textbooks: low) is very unfavorable for college students to receive the morality cultivation education. Therefore, in the compilation of College English textbooks in the future, it should be clearly stated that the compilation purpose and content of the textbooks are moral education and ideologi- 
cal and political service [11]. At the same time, the content proportion of the morality cultivation in College English textbooks should be increased (such as about 30\%). Ideological and political contents, such as communism and socialist core values, excellent traditional Chinese culture and national feelings, are included in the College English textbooks in the future to achieve the goal of improving college students' English ability and ideological and political literacy.

The results in this paper show that the ideological and political education plays a positive role in promoting the English learning of college freshmen. The results in this study agree with those of Huang [10], "Proper amount of content on the morality cultivation can significantly promote college English teaching". This promotion in the College English teaching is inseparable from teachers' active and correct guidance (such as discussing ideological and political topics, comparing Chinese and Western cultures, using online resources related to ideological and political education for students to study independently before class), and teaching methods such as reflections, textbook drama videos and social practice used for freshmen to receive the ideological and political education in the College English courses. Freshmen students' needs and expectations related to English learning and the morality cultivation are met through teachers' positive, correct guidance and appropriate teaching methods used in the teaching of the morality cultivation in College English, so that College English courses and ideological and political theory courses are in the same direction to form a synergistic effect.

College English can be a course that meets the needs and expectations of college students' growth and development, goes in the same direction with the ideological and political theory courses to form a synergistic effect. During the teaching of the morality cultivation applied in the course: College English, teachers and students can use English to study and discuss the content on knowledge related to Chinese culture, Chinese system knowledge, and career planning to promote college students' understanding for Chinese excellent cultural knowledge, Chinese system knowledge, and future Career planning, to raise their confidence in Chinese culture, the Chinese social system, and to strengthen college students' sense of identity with Chinese culture, national identity, and professional identity. However, college students may receive the negative impacts from Western ideologies, cultural systems, and lifestyles, because English is one of the western languages related to western culture, and English articles in the current English textbooks and other English audio and video will involve a large number of Western ideologies, cultural systems, and lifestyles. Therefore, college English teachers should correctly guide college students in terms of ideals, beliefs, ideals and beliefs, ethics, and aesthetic appeal and help college students know how to resist the influence of bad ideology, cultural system and lifestyles on their growth. In the future, the College English teachers may combine the correct information related to ideals, beliefs, ideals and beliefs, ethics, and aesthetic appeal into their College English teaching through different activities such as the English speech- 
es, introduction of good Chinese traditional culture.

\section{Limitations and Suggestions for Further Research}

There are limitations and suggestions for Further Research in this article.

Firstly, the subjects in the study consisted of only 174 non-English-majored undergraduate freshmen in one university, which is needed to be broadened in further research.

Secondly, the instrument used in this study to investigate the non-Englishmajored undergraduate freshmen students' views and needs on the morality cultivation in College English involves only questionnaire. The study would be much better, if it were combined with other instruments such as interview. More instruments should be used in investigating in the further research.

Finally, subjects in this study were the non-English-majored undergraduate freshmen students from only one university. The study will be better if more subjects from other local universities can be participated in the experiment.

Despite of the restraints of the study, we hope that it can offer some guidelines for further research of the morality cultivation on non-English-majored undergraduate freshmen students' College English.

\section{Conclusion}

In this paper, 174 freshmen in Yangtze University were surveyed on their opinions and needs on the morality cultivation applied in College English courses. According to the results in this paper, we know that college freshmen in Yangtze university generally accept the new teaching concept of integrating ideological and political elements into college English courses, but students believe that the proportion of ideological and political content in college English textbooks is low, and the content on Chinese cultural knowledge content, Chinese system knowledge content, career planning content, etc. may be incorporated into College English textbooks because the education on ideological and political content not only does not hinder their English learning, but also promotes their English learning. In the teaching of the morality cultivation in College English courses, college English teachers should correctly guide college students in terms of ideals and beliefs, ideals and beliefs, ethics and aesthetic appeal, which will help college students to grow up well.

\section{Fund}

This article is phased results of Yangtze University's teaching research program (Program title "An Action Research on Graduate EAP Teaching under the Concept of Ideological and Political Education in Curricula" (Program NO. JY2020055)).

\section{Conflicts of Interest}

The author declares no conflicts of interest. 


\section{References}

[1] Xi, J.P. (2016) Putting Morality Cultivation through the Whole Process of Education and Teaching to Create a New Situation for the Development of China's Higher Education. The People Daily, December 9, 2016.

[2] The Ministry of Education of the People's Republic of China. (2018) Opinions from the Ministry of Education of the People's Republic of China on Accelerating the Construction of High-level Undergraduate Education to Comprehensively Improve the Ability to Cultivate Talents.

http://www.moe.gov.cn/srcsite/A08/s7056/201810/t20181017 351887.html

[3] The Ministry of Education of the People's Republic of China (2020) Guidelines for the Construction of Curricula Related to the Morality Cultivation in Colleges and Universities.

[4] Shen, J.X., Qi, J.J., Ma, G.H. and Zheng, C.J. (2018) Ideological and Political Education in Curriculum of Traffic Engineering: An Example of Traffic Environmental Impact Assessment Course. Educational Sciences. Theory \& Practice, 18, 2864-2873.

[5] Chen, X.Z. (2019) The Teaching Realization of the Morality Cultivation Applied in College English from the Perspective of Optimization Theory. China University Teaching, 10, 45-48.

[6] Xia, W.H. and He, F. (2019) The Mission of the Morality Cultivation Applied in College English. People's Tribune, 30, 108-109.

[7] He, W. (2019) Research on Integration of "Ideological and Political Education of Course" into the Teaching Path of College English Course. Journal of Zhongzhou University, 36, 96-100.

[8] Shi, Y.J. (2019) Exploration on the Teaching Reform of "Curriculum on the Morality Cultivation" in Public English Courses in Political and Law Colleges. The Party Building and Ideological Education in Schools, 4, 30-32.

[9] Huang, B.H. (2020) On College English Teaching Reform Practice from the Perspective of Ideological and Political Education: Case Study of Zhejiang Sci-Tech University. Journal of Zhejiang Sci-Tech University, 44, 1-7.

[10] Jia, F. and Shen Y.X. (2020) Evaluating Going Global in the Framework of POA: From Teachers' Perspective. Foreign Language Education in China, 3, 19-26.

[11] Liu, Z.G. and Yue, M.M. (2020) Resetting the Educational Philosophy and Restructuring Learning Content to Implement Morality Cultivation in Foreign Language Course Instruction. Journal of Foreign Languages, 43, 21-29. 